\title{
Despite a Massive Increase in Cortisol Secretion in Women During Parturition, There is an Equally Massive Increase in Prostaglandin Synthesis
}

\author{
A Paradox? \\ M. Linette Casey, Paul C. MacDonald, and Murray D. Mitchell \\ Cecil H. and Ida Green Center for Reproductive Biology Sciences and the Departments of Biochemistry and Obstetrics-Gynecology, \\ The University of Texas Southwestern Medical School, Dallas, Texas 75235
}

\begin{abstract}
In this investigation, we sought to resolve the apparent paradox that is posed by the fact that there is a simultaneous increase in the production of prostaglandin and cortisol in women during labor. A paradox obtains, since in most tissues, cortisol acts to inhibit prostaglandin formation. Using previously characterized model systems for the in vitro study of arachidonic acid metabolism in amnion, decidua, and myometrium, we found that prostaglandin production by amnion and endometrial stromal cells in monolayer culture was not decreased by glucocorticosteroid treatment. On the other hand, prostaglandin production by myometrial smooth muscle cells in culture was inhibited by $>90 \%$ in response to dexamethasone $\left(10^{-7} \mathrm{M}\right)$ treatment. Importantly, the major prostaglandin produced by myometrium, as well as myometrial smooth muscle cells in culture, is prostacyclin, a prostaglandin that acts to cause uterine quiescence. We suggest that the immunity of amnion and decidua to the action of glucocorticosteroids may allow for the accelerated production of prostaglandins $E_{2}$ and $F_{2 \alpha}$, which act to cause myometrial contractions; simultaneously, glucocorticosteroid produced in large quantities in women in labor may lead to decreased production of prostacyclin by myometrium, thereby reducing uterine quiescence. In this coordinated manner, the uterine contractions that culminate in delivery of the fetus may proceed uninterrupted in the face of increased cortisol production.
\end{abstract}

\section{Introduction}

Among the biochemical events that are characteristic of labor and delivery in pregnant women at term, increases in the plasma levels of cortisol (1-3) and prostaglandins (4-9) are striking. These two phenomena almost invariably accompany parturition in women; nonetheless, the coexistence of these processes seemingly constitutes a biologic paradox since glucocorticosteroids act, in most tissues, to effect inhibition of prostaglandin synthesis. In Table I, a compendium of the

Dr. Mitchell's present address is Department of Ophthalmology, University of California at San Diego, CA 92103.

Address correspondence to Dr. Casey, Cecil H. and Ida Green Center for Reproductive Biology Sciences, The University of Texas Southwestern Medical School, 5323 Harry Hines Blvd., Dallas, TX 75235.

Received for publication 7 August 1984 and in revised form 29 January 1985.

J. Clin. Invest.

(C) The American Society for Clinical Investigation, Inc.

$0021-9738 / 85 / 06 / 1852 / 06 \$ 1.00$

Volume 75, June 1985, 1852-1857 results of other investigators (10-33) who have demonstrated the effectiveness of glucocorticosteroids in the inhibition of prostaglandin synthesis in a variety of tissues is presented. Yet, in pregnant women in labor, in whom accelerated production of prostaglandins appears to be essential to the maintenance of uterine contractions and, thereby, the successful delivery of the fetus, there must be a means of circumventing the inhibition of prostaglandin synthesis that commonly is associated with glucocorticosteroid action. We considered it important, therefore, to evaluate the effect of glucocorticosteroids on prostaglandin production in tissues that are believed to be those principally involved in the biosynthesis of the prostaglandins that are important in the initiation and maintenance of parturition in women.

The findings of many studies (for review, 34-36) are supportive of the proposition that, in human pregnancy, the amnion is a key tissue in the metabolic events that lead ultimately to the initiation of labor. It is known that in avascular human amnion, there is a prodigious capacity for the biosynthesis of prostaglandin (PG) $\mathrm{E}_{2}$ (37-39). Uterine decidua vera, the specialized endometrium of pregnancy that is derived from endometrial stroma, also is known to be a site of $\mathrm{PGE}_{2}$ and $\mathrm{PGF}_{2 \alpha}$ synthesis (37-39). In myometrial tissue, there also is a significant capacity for the biosynthesis of prostaglandins. The nature of the prostaglandins biosynthesized in myometrium, however, is different from that in amnion or decidua vera. Specifically, myometrial tissue is known to produce large quantities of prostacyclin $\left(\mathrm{PGI}_{2}\right)(40-42)$, which, in contrast with $\mathrm{PGE}_{2}$ and $\mathrm{PGF}_{2 \alpha}$, acts to effect uterine quiescence $(43,44)$.

The effectiveness of this coordinated pattern of prostaglandin biosynthesis that culminates in the birth of the fetus at term could be disrupted if cortisol, which is produced in large amounts during labor, acted to inhibit synthesis of the prostaglandins that effect the contractions of the uterus. To investigate the nature of the biologic counterbalances that permit augmented prostaglandin biosynthesis and augmented cortisol secretion simultaneously, we evaluated the effect of glucocorticosteroids on prostaglandin formation by human amnion cells, human endometrial stromal cells, and human myometrial smooth muscle cells that were maintained in monolayer culture.

\section{Methods}

Tissues. Human amnion tissues were obtained from placentae after delivery at term by elective Cesarean section. Endometrial and myometrial tissues were obtained from the uteri of women within $1 \mathrm{~h}$ of hysterectomy that was conducted for reasons other than organic disease

1. Abbreviations used in this paper: $\mathrm{PG}$, prostaglandin; $\mathrm{PGI}_{2}$, prostacyclin. 
Table I. Tissues in which Glucocorticosteroids Are Known to Act to Reduce Prostaglandin Synthesis

\begin{tabular}{lll}
\hline Tissue & Species & Reference \\
\hline Lung & Guinea pig & 13,14 \\
Mesentery artery & Rabbit & 13 \\
Fibrosarcoma cells & Mouse & 15 \\
Rheumatoid synovia & Human & 16 \\
& Rat & 17 \\
Synovial fibroblasts & Human & 18 \\
Adipose tissue & Rabbit & 19 \\
& Human & 20 \\
Transformed fibroblasts & Mouse & 21,22 \\
Macrophages & Guinea pig & 23 \\
& Mouse & 24,25 \\
Fibroblasts & Human & 26 \\
& Mouse & 27 \\
Leukocytes & Rat & 28,29 \\
Kidney & Rabbit & 30 \\
Lymphocytes & Rat & 31 \\
Granuloma & Human & 32 \\
Platelets & Rat & 33 \\
Endothelium & Human & 34 \\
Adrenal cortex & Rat & 34 \\
Trabecular cells & Human (fetal) \\
& Human & 35 \\
\hline
\end{tabular}

of the tissue (endometrium or myometrium) that was obtained. Consent in writing to use these tissues was given by the women who were to undergo surgery; the consent form and experimental protocol were approved by the Human Experimentation Review Committee of the University of Texas Health Science Center.

Cells in culture. Dispersed amnion cells were prepared by enzymatic digestion of amnion tissue as described in detail previously (45). The cells were placed in 24-well (15-mm diam) culture plates and were maintained in primary monolayer culture in a mixture $(1: 1, \mathrm{vol} / \mathrm{vol})$ of Dulbecco's and Ham's F12 culture medium that contained antibioticantimycotic solution ( $1 \%$, by volume) and heat-inactivated fetal calf serum $(10 \%$, by volume). These cells replicate to confluence in 7-10 d.

Endometrial stromal cells were prepared as described previously (46). Briefly, endometrial glandular epithelium and dispersed endometrial stromal cells were prepared by enzymatic digestion of minced endometrial tissue. The endometrial glands and stromal cells were separated by filtration through a sieve that retains the glands. The stromal cells were placed in culture flasks and were maintained in Waymouth-enriched medium that contained Waymouth MB752/1 medium, minimum essential medium vitamins, minimum essential medium amino acids, nonessential amino acids, antibiotics, antimycotics, and fetal calf serum ( $10 \%$, by volume) as described previously in detail (46). These cells replicate to confluence and are passed by standard methods of trypsinization, dilution, and replating also as described previously (46). The endometrial stromal cells maintained characteristic patterns of prostaglandin production for as many as $\mathbf{1 0}$ passages.

Myometrial smooth muscle cells were prepared by relatively longterm (4-8 h) enzymatic digestion of myometrial tissue, as described in detail previously (47). The dispersed cells were placed in culture flasks and were maintained in Waymouth-enriched culture medium that contained fetal calf serum (10\%, by volume) and was identical with that used for endometrial stromal cells. These cells replicated in culture and retained characteristic patterns of prostaglandin production for as many as 10 passages.
All cells were maintained at $37^{\circ} \mathrm{C}$ in a atmosphere of air and $\mathrm{CO}_{2}$ (5\%). Prior to the conduct of each study, endometrial stromal cells and myometrial smooth muscle cells were placed in 24-well (15-mm diam) culture plates. All studies were conducted with confluent cells in replicates of six wells of cells for each experimental condition. Each experiment was conducted with cells that were prepared from tissue(s) that were obtained from one woman. Each study was conducted on three or more occasions with cells prepared from tissues that were obtained from different women. Culture media $(1 \mathrm{ml} /$ well $)$ corresponded to that which was used for maintenance of each cell type. At the commencement of the incubation period, the culture medium was changed to one that contained ethanol $(0.1 \% \mathrm{vol} / \mathrm{vol})$ or dexamethasone (dissolved in ethanol), in various concentrations $\left(10^{-11}-10^{-6} \mathrm{M}\right)$. The concentration of ethanol $(0.1 \%$, vol/vol) was maintained constant in all experiments. At various times thereafter, the culture media in different wells were collected and frozen at $-20^{\circ} \mathrm{C}$; at each time, the cells were rinsed with serumless medium and were frozen at $-20^{\circ} \mathrm{C}$ for determination of protein content.

Evaluation of prostaglandin production. $\mathrm{PGE}_{2}, \mathrm{PGF}_{2 \alpha}$, and 6-keto$\mathrm{PGF}_{1 \alpha}$ (the stable, nonenzymatically formed product of $\mathrm{PGI}_{2}$ ) in the culture media were measured by sensitive and specific radioimmunoassays that have been validated and described in detail $(48,49)$. The total cellular protein in each well was quantified by the method of Lowry et al. (50).

\section{Results}

The time course of $\mathrm{PGE}_{2}$ production by amnion cells in monolayer culture is illustrated in Fig. 1. The amount of $\mathrm{PGE}_{2}$ in the culture medium was maximal after $12 \mathrm{~h}$ and remained relatively constant thereafter. Dexamethasone $\left(10^{-7} \mathrm{M}\right)$, when added to the culture medium, did not cause inhibition of $\mathrm{PGE}_{2}$ biosynthesis but, rather, resulted in a small increase in $\mathrm{PGE}_{2}$ biosynthesis (Fig. 2). In this study, amnion cells were treated with dexamethasone $\left(10^{-7} \mathrm{M}\right)$, and the culture media were collected and replaced daily for $72 \mathrm{~h}$. The stimulation by dexamethasone of $\mathrm{PGE}_{2}$ production, as determined by measurement of $\mathrm{PGE}_{2}$ in the media collected on day 2 and day 3 , was statistically significant (day $2, P<0.02$; day $3, P<0.005$ ).

The time course of $\mathrm{PGE}_{2}$ and $\mathrm{PGF}_{2 \alpha}$ production by endometrial stromal cells in monolayer culture is presented in Fig. 3. The amounts of $\mathrm{PGE}_{2}$ and $\mathrm{PGF}_{2 \alpha}$ in the culture medium increased in a linear fashion up to $12 \mathrm{~h}$ but decreased slightly thereafter, possibly as a result of metabolism of these prostaglandins. $\mathrm{PGE}_{2}$ and $\mathrm{PGF}_{2 \alpha}$ production by confluent endometrial

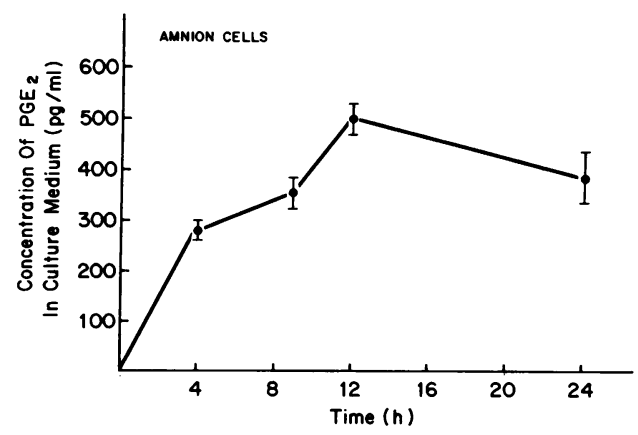

Figure 1. Time course of $\mathrm{PGE}_{2}$ production (mean $\pm \mathrm{SEM}, n=6$ ) by confluent human amnion cells in primary monolayer culture. The culture medium was charged at zero time and was collected from different wells at various times thereafter for assay of $\mathrm{PGE}_{2}$. Each dish contained $1 \mathrm{ml}$ of culture medium and $118 \pm 2 \mathrm{mg}$ cell protein (mean \pm SEM). 


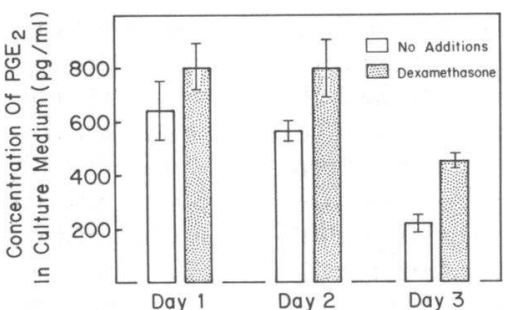

Figure 2. Effect of dexamethasone treatment on $\mathrm{PGE}_{2}$ production (mean \pm SEM, $n=6$ ) by human amnion cells in monolayer culture. The cells were incubated with culture media that did not or did contain dexamethasone $\left(10^{-7} \mathrm{M}\right)$ for $24 \mathrm{~h}$; thereafter, the culture media were collected for assay of $\mathrm{PGE}_{2}$. Treatment without or with dexamethasone was continued for $2 \mathrm{~d}$. Each dish contained $1 \mathrm{ml}$ of culture medium and $127 \pm 3 \mathrm{mg}$ cell protein (mean \pm SEM).

stromal cells that were incubated in the absence or presence of dexamethasone $\left(10^{-7} \mathrm{M}\right)$ for $3 \mathrm{~d}$ was evaluated; the culture medium was collected daily. Treatment with dexamethasone $\left(10^{-7} \mathrm{M}\right)$ did not affect either $\mathrm{PGE}_{2}$ or $\mathrm{PGF}_{2 \alpha}$ production in a consistent manner (Figs. $4 A$ and $B$ ).

The time course of $\mathbf{P G I}_{2}$ (measured as the stable, nonenzymatically formed metabolite, 6-keto- $\mathrm{PGF}_{1 \alpha}$ ) production by myometrial cells in monolayer culture is illustrated in Fig. 5. The amount of $\mathrm{PGI}_{2}$ in the culture medium of cells that were not treated with dexamethasone increased during the 24-h period of study. Dexamethasone $\left(10^{-7} \mathrm{M}\right)$, when added to the culture medium, inhibited $\mathrm{PGI}_{2}$ production in a manner that was apparent within $8 \mathrm{~h}$ of treatment (Fig. 5). The extent of inhibition of $\mathrm{PGI}_{2}$ production was dependent on the concentration of dexamethasone in the culture medium (Fig. 6). The concentration of dexamethasone that caused a $50 \%$ reduction in $\mathrm{PGI}_{2}$ production was between $10^{-9}$ and $10^{-10} \mathrm{M}$.

\section{Discussion}

An essential role for prostaglandin in the induction of the myometrial contractions that lead to the delivery of the fetus is well-established. Indeed, the administration of prostaglandin(s) to pregnant women at any stage of gestation, by any of a number of different routes, leads to the onset of labor $(51$, 52). In addition, prostaglandin synthase inhibitors, when ad-

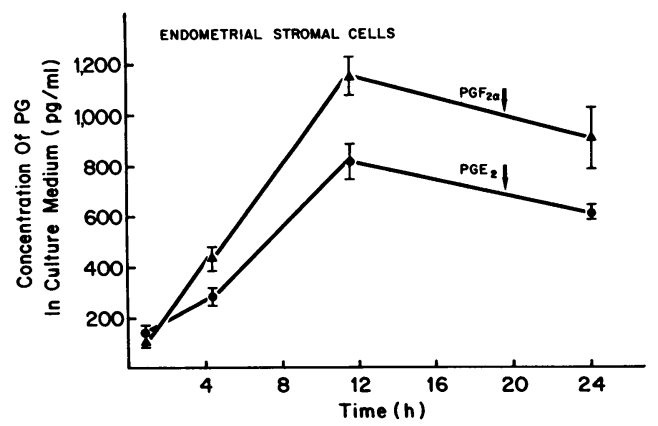

Figure 3. Time course of $\mathrm{PGE}_{2}$ and $\mathrm{PGF}_{2 \alpha}$ production (mean $\pm \mathrm{SEM}$, $n=6$ ) by confluent human endometrial stromal cells in monolayer culture. The culture medium was changed at zero time and was collected from different wells at various times thereafter for assay of $\mathrm{PGE}_{2}$ and $\mathrm{PGF}_{2 \alpha}$. Each dish contained $1 \mathrm{ml}$ of culture medium and $97 \pm 1 \mathrm{mg}$ cell protein (mean $\pm \mathrm{SEM}$ ).
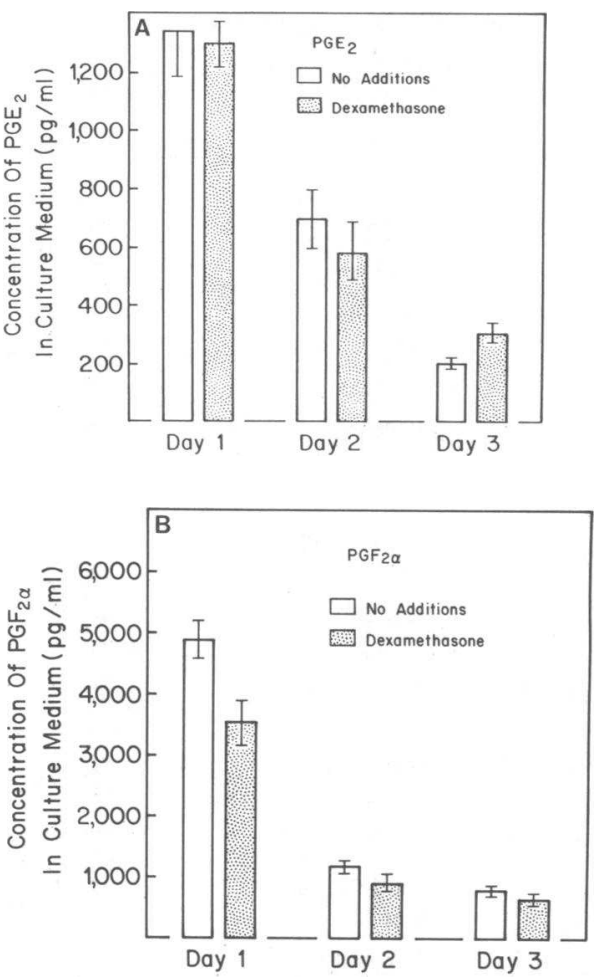

Figure 4. Effect of dexamethasone treatment on $\mathrm{PGE}_{2}(A)$ and $\mathrm{PGF}_{2 \alpha}$ $(B)$ production by human endometrial stromal cells in monolayer culture. Cells at confluence were incubated with culture media that did not or did contain dexamethasone $\left(10^{-7} \mathrm{M}\right)$ for $24 \mathrm{~h}$; thereafter, the culture media were collected for assay of $\mathrm{PGE}_{2}(A)$ and $\mathrm{PGF}_{2 \alpha}$ $(B)$. The same protocol was followed on day 2 and day 3 of the study. Each dish contained $1 \mathrm{ml}$ of culture media and $103 \pm 1 \mathrm{mg}$ cell protein $($ mean $\pm \mathrm{SEM})$.

ministered to pregnant women, cause prolonged gestation, cessation of preterm labor, and a lengthening of the time interval for induction of abortion by the instillation of hyper-

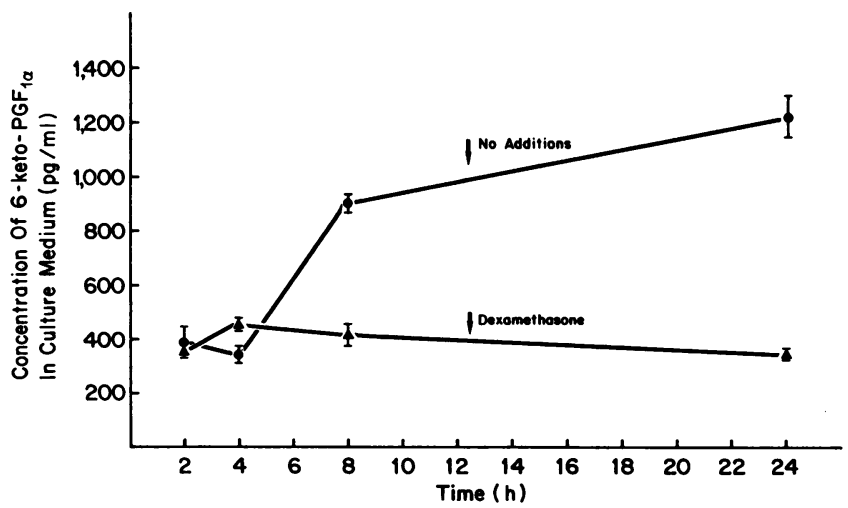

Figure 5. Time course of $\mathrm{PGI}_{2}$ production (mean $\pm \mathrm{SEM}, n=6$ ) by confluent human myometrial smooth muscle cells in monolayer culture in the absence or presence of dexamethasone $\left(10^{-7} \mathrm{M}\right)$. The culture medium was changed at zero time and was collected at various times thereafter for assay of 6-keto-PGF ${ }_{1 \alpha}$. Each dish contained $1 \mathrm{ml}$ of culture medium; the protein content in dishes that contained cells treated with dexamethasone was $143 \pm 9 \mathrm{mg}$ cell protein (mean \pm SEM) and, in those that contained medium without dexamethasone, it was $149 \pm 7 \mathrm{mg}$ cell protein. 


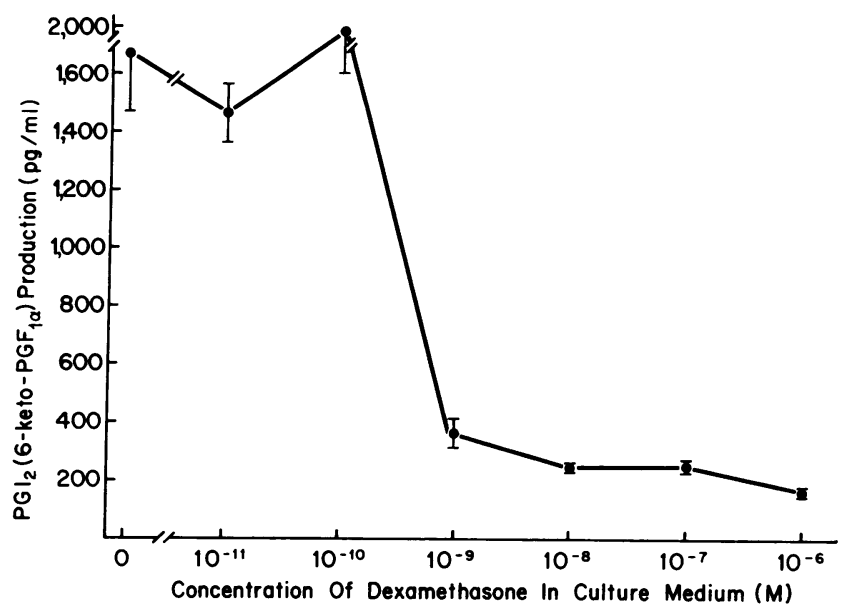

Figure 6. Effect of dexamethasone, in various concentrations, on $\mathrm{PGI}_{2}$ production (mean $\pm \mathrm{SEM}, n=6$ ) by human myometrial smooth muscle cells in monolayer culture. Confluent cells were incubated with culture medium that did not or did contain dexamethasone for $24 \mathrm{~h}$; thereafter, the culture media were collected for assay of 6-keto$\mathrm{PGF}_{1 \alpha}$. Each dish contained $1 \mathrm{ml}$ of culture medium and $179 \pm 6 \mathrm{mg}$ cell protein (mean $\pm \mathrm{SEM}$ ).

tonic saline into the amniotic fluid (53). A striking increase in the rate of cortisol secretion is also associated with labor in women (1-3). The apparent paradox of these coexistent biologic phenomena evolves about the well-known action of glucocorticosteroids to inhibit PG production. In consideration of this apparent paradox, we evaluated the effect of glucocorticosteroids on PG production in amnion cells, endometrial stromal cells, and myometrial smooth muscle cells that are maintained in monolayer culture.

Previously, we presented evidence that the morphologic and biochemical characteristics of these cells in monolayer culture are similar to those of the tissues from which the cells were derived. In human amnion tissue, there is a single cell type; and, after dispersion of these cells and replication in vitro, the morphology, the glycerophospholipid composition, the arachidonic acid distribution (45), and the pattern of prostaglandin synthesis and metabolism (54), as well as the characteristics of the enzymes that catalyze the release of arachidonic acid in these cells (45), are very similar to those of amnion tissue. Similarly, arachidonic acid metabolism in human endometrial stromal cells (from which decidua arises) that are maintained in monolayer culture, are very similar to decidual tissue (46). Human myometrial smooth muscle cells that are maintained in monolayer culture also appear to be an appropriate model system for the study of this tissue (47). Of utmost importance for the purposes of this study, the pattern of and the capacity for prostaglandin synthesis in these cells in vitro appear to be similar to, if not identical with, those known to be characteristic for the tissue from whence each cell type was derived. We cannot be absolutely certain, however, that these cells maintained in culture respond to glucocorticosteroids in a manner that is identical with that in vivo. In addition, the possibility exists that endometrial stromal cells and myometrial smooth muscle cells prepared from tissue that are obtained from nonpregnant women respond in a manner that is not identical with that of decidual cells and myometrial smooth muscle cells that are prepared from tissues of pregnant women. Nonetheless, we suggest that the findings of the present investigation are suggestive of a resolution to the apparent cortisol-prostaglandin paradox. We suggest that the high rate of cortisol production in pregnant women during labor does not cause inhibition of the synthesis of prostaglandins that act to induce and maintain the myometrial contractions of labor. This obtains since amnion and endometrial stromal cells are refractory to the action of glucocorticosteroids, unlike many other tissues in which glucocorticosteroids are known to act to suppress prostaglandin synthesis. Thus, despite striking increases in cortisol levels in blood of women as labor progresses, the amnion and decidua may continue to synthesize and secrete prostaglandins, which are agents that are believed to be required for the completion of the parturient process. On the other hand, the myometrial smooth muscle cells respond to glucocorticosteroids by a reduction in synthesis of $\mathrm{PGI}_{2}$, and thereby may serve to relieve the myometrial smooth muscle cell of $\mathrm{PGI}_{2}$-effected quiescence. In this manner, we envision that the unbridled production of $\mathrm{PGE}_{2}$ and $\mathrm{PGF}_{2 \alpha}$ in amnion and decidua gives rise, in concert with decreased myometrial $\mathrm{PGI}_{2}$ production, to an unimpeded response to the prostaglandins that elicit contractions; therein may reside the solution to the apparent cortisol-prostaglandin paradox of labor in women.

In association with the stress-induced increase in cortisol secretion in women during labor, which now may be considered as complementary to the mechanisms that perpetuate the effectiveness of the work forces of labor, there may be yet another complementary metabolic event that is characteristic of the "fight or flight" phenomenon. During this time in labor, there also is an increase, of considerable magnitude, in the levels of circulating catecholamines (56), substances that are known to effect lipolysis in adipose tissue stores, and thereby, an increase in free fatty acids comes about (57); and, in this manner, depleted stores of arachidonic acid in amnion and decidua may be replenished. Therefore, in women, labor may serve as a stimulus, by way of well-known responses to stress, to ensure the completion of the parturitional process.

\section{Acknowledgments}

We thank Sue MacDonald and Susan Rawlins for assistance in obtaining tissues, Patrick Keller, Jess Smith, and Tina Rayfield for skilled technical assistance, and Rosemary Bell for expert editorial assistance.

This investigation was supported, in part, by U. S. Public Health Service grants nos. 5-P50-HD11149 and 2-P01-AG00306.

\section{References}

1. Krauer, F. 1973. Maternal and umbilical cord plasma cortisol concentrations related to different types of deliveries. Arch. Gynecol. 215:343-350.

2. Dormer, R. A., and J. T. France. 1973. Cortisol and cortisone levels in umbilical cord plasma and maternal plasma of normal pregnancies. Steroids. 21:497-510.

3. Carr, B. R., C. R. Parker, J. D. Madden, P. C. MacDonald, and J. C. Porter. 1981. Maternal plasma adrenocorticotropin and cortisol relationships throughout human pregnancy. Am. J. Obstet. Gynecol. 139:416-422.

4. MacDonald, P. C., F. M. Schultz, J. H. Duenhoelter, N. F. Gant, J. M. Jimenez, J. A. Pritchard, J. C. Porter, and J. M. Johnston 1974. Initiation of human parturition: mechanism of action of arachidonic acid. Obstet. Gynecol. 44:629-635. 
5. Hamberg, M. 1974. Quantitative studies on prostaglandin synthesis in man. III. Excretion of the major metabolite of prostaglandin $F_{1}$ and $F_{2}$ during pregnancy. Life Sci. 14:247-252.

6. Green, K., M. Bygdeman, M. Toppozada, and N. Wiqvist. 1976. The role of prostaglandin $F_{2 \alpha}$ in human parturition: endogenous plasma levels of 15-keto-13,14-dihydroprostaglandin $\mathrm{F}_{2 \alpha}$. Am. J. Obstet. Gynecol. 120:25-31.

7. Keirse, M. J. N. C., M. D. Mitchell, and A. C. Turnbull. 1977. Changes in prostaglandin $F$ and 13,14-dihydro-15-keto-prostaglandin $F$ concentrations in amniotic fluid at the onset of and during labor. Br. J. Obstet. Gynaecol. 84:743-746.

8. Satoh, K., T. Yasumizu, H. Fukuoka, K. Kinoshita, Y. Kaneko, M. Tsuchiya, and S. Sakamoto. 1979. Prostaglandin $F_{2}$ metabolite levels in plasma, amniotic fluid and urine during pregnancy and labor. Am. J. Obstet. Gynecol. 133:886-890.

9. Ghodgaonkar, R. B., N. H. Dubin, D. A. Blake, and T. M. King. 1979. 13,14-Dihydro-15-keto-prostaglandin $F_{2 \alpha}$ concentrations in human plasma and amniotic fluid. Am. J. Obstet. Gynecol. 134: 265-269.

10. Gryglewski, R. J., B. Panczenko, R. Korbut, L. Grodzinska, and A. Ocetkiewicz. 1975. Corticosteroids inhibit prostaglandin release from perfused mesenteric blood vessels of rabbit and from perfused lungs of sensitized guinea pig. Prostaglandins. 10:343-355.

11. Flower, R. J., and G. J. Blackwell. 1979. Anti-inflammatory steroids induce biosynthesis of a phospholipase $A_{2}$ inhibitor which prevents prostaglandin generation. Nature (Lond.). 278:456-459.

12. Tashjian, A. H., Jr., E. F. Voelkel, J. McDonough, and L. Levine. 1975. Hydrocortisone inhibits prostaglandin production by mouse fibrosarcoma cells. Nature (Lond.). 258:739-741.

13. Kantrowitz, F., D. R. Robinson, M. B. McGuire, and L. Levine. 1975. Corticosteroids inhibit prostaglandin production by rheumatoid synovia. Nature (Lond.). 258:737-739.

14. Floman, Y., and U. Zor. 1976. Mechanism of steroid action in inflammation: inhibition of prostaglandin synthesis and release. Prostaglandins. 12:403-413.

15. Newcombe, D. S., J. V. Fahey, and Y. Ishikawa. 1977. Hydrocortisone inhibition of the bradykinin activation of human synovial fibroblasts. Prostaglandins. 13:235-244.

16. Lewis, G. P., and P. J. Piper. 1975. Inhibition of release of prostaglandins as an explanation of some of the actions of antiinflammatory corticosteroids. Nature (Lond.). 254:308-311.

17. Mitchell, M. D., W. H. Cleland, M. E. Smith, E. R. Simpson, and C. R. Mendelson. 1983. Inhibition of prostaglandin biosynthesis in human adipose tissue by glucocorticosteroids. J. Clin. Endocrinol. Metab. 57:771-776.

18. Hong, S. L., and L. Levine. 1976. Inhibition of arachidonic acid release from cells as the biochemical action of anti-inflammatory corticosteroids. Proc. Natl. Acad. Sci. USA. 73:1730-1734.

19. Tam, S., S. L. Hong, and L. Levine. 1977. Relationships, among the steroids, of anti-inflammatory properties and inhibition of prostaglandin production and arachidonic acid release by transformed mouse fibroblasts. J. Pharmacol. Exp. Ther. 203:162-168.

20. Bray, M. A., and D. Gordon. 1976. Effects of anti-inflammatory drugs on macrophage prostaglandin biosynthesis. Br. J. Pharmacol. 57:466-467P.

21. Glatt, M., H. Kalin, K. Wagner, and K. Brune. 1977. Prostaglandin release from macrophages: an assay system for anti-inflammatory drugs in vitro. Agents Actions. 7:321-326.

22. Hamilton, J. A. 1981. Regulation of prostaglandin and plasminogen activator production by mouse peritoneal macrophages. $J$. Reticuloendothel. Soc. 30:115-128.

23. Yaron, M., I. Yaron, D. Gurari-Rotman, M. Revel, H. R. Lindner, and U. Zor. 1977. Stimulation of prostaglandin E production in cultured human fibroblasts by poly(I)poly(C) and human interferon. Nature (Lond.). 267:457-459.

24. Chandrobose, K. A., E. G. Lapetina, C. J. Schmitges, M. I. Siegel, and P. Cuatrecasas. 1978. Action of corticosteroids in regulation of prostaglandin biosynthesis in cultured fibroblasts. Proc. Natl. Acad. Sci. USA. 75:214-217.

25. Parente, L., G. Ammendola, P. Persico, and M. DiRosa. 1978. Glucorticosteroids, prostaglandins and the inflammatory process. Pol. J. Pharmacol. Pharm. 30:141-155.

26. Blackwell, G. J., R. Carnuccio, M. DiRosa, R. J. Flower, L. Parente, and P. Persico. 1980. Macrocortin: a polypeptide causing the antiphospholipase effect of glucocorticoids. Nature (Lond.). 287:147149.

27. Hirata, F., E. Schiffmann, K. Venkatasubramanian, D. Salomon, and J. Axelrod. 1980. A phospholipase $A_{2}$ inhibitory protein in rabbit neutrophils induced by glucocorticoids. Proc. Natl. Acad. Sci. USA. 77:2533-2536.

28. Russo-Marie, F., M. Paing, and D. Duval. 1979. Involvement of glucocorticoid receptors in steroid-induced inhibition of prostaglandin secretion. J. Biol. Chem. 254:8489-8504.

29. Staszak, C., and J. S. Goodwin. 1980. Is prostaglandin a mediator for the inhibitory action of histamine, hydrocortisone, and isoproterenol? Cell. Immunol. 54:351-361.

30. Ohuchi, K., H. Sato, T. Komabayashi, S. Tsurufuji, H. Satoh, and L. Levine. 1980. Prostaglandin production by minced carrageenin granuloma tissue of rats and its inhibition by dexamethasone and cycloheximide. Prostagl. Med. 5:267-274.

31. Jorgensen, K. A., and E. Stoffersen. 1981. Hydrocortisone inhibits platelet prostaglandin and endothelial prostacyclin production. Pharmacol. Res. Commun. 13:579-586.

32. Mitchell, M. D., B. R. Carr, J. I. Mason, and E. R. Simpson. 1982. Prostaglandin biosynthesis in the human fetal adrenal gland: regulation by glucocorticosteroids. Proc. Natl. Acad. Sci. USA. 79: 7547-7551.

33. Weinreb, R. N., M. D. Mitchell, and J. R. Polansky. 1983. Prostaglandin production by human trabecular cells: in vitro inhibition by dexamethasone. Invest. Ophthalmol. Visual. Sci. 24:1541-1545.

34. Casey, M. L., C. A. Winkel, J. C. Porter, and P. C. MacDonald. 1983. Endocrine regulation of the initiation and maintenance of parturition. Clin. Perinatol. 10:709-721.

35. Mitchell, M. D. 1984. The mechanism(s) of human parturition. J. Dev. Physiol. (Oxf.). 6:107-118.

36. Bleasdale, J. E., and J. M. Johnston. 1984. Prostaglandins and human parturition: regulation of arachidonic acid mobilization. Rev. Perinatal Med. 5:151-191.

37. Kinoshita, K., K. Satoh, and S. Sakamoto. 1977. Biosynthesis of prostaglandin in human decidua, amnion, chorion and villi. Endocrinol. Jpn. 24:343-350.

38. Mitchell, M. D., J. Bibby, B. R. Hicks, and A. C. Turnbull. 1978. Specific production of prostaglandin $E$ by human amnion in vitro. Prostaglandins. 15:377-382.

39. Okazaki, T., M. L. Casey, J. R. Okita, P. C. MacDonald, and J. M. Johnston. Initiation of human parturition. XII. Biosynthesis and metabolism of prostaglandins in human fetal membranes and uterine decidua. Am. J. Obstet. Gynecol. 139:373-381.

40. Barnford, D. S., M. Jogee, and K. I. Williams. 1980. Prostaglandin formation by the pregnant human myometrium. Br. J. Obstet. Gynaecol. 87:215-218.

41. Sanger, G. J., C. N. Hensby, I. F. Stamford, and A. Bennett. 1981. Identification of arachidonic acid metabolites extracted from human uterus, and their effects on the isolated myometrium. J. Pharm. Pharmacol. 33:607-610.

42. Satoh, K., T. Yasumizu, Y. Kawai, A. Ozaki, T. Wu, K. Kinoshita, and S. Sakamoto. 1981. In vitro production of prostaglandins $E$, F, and 6-keto-prostaglandin $F_{1 \alpha}$ by human pregnant uterus, decidua and amnion. Prostagl. Med. 6:359-368.

43. Lye, S. J., and J. R. G. Challis. 1982. Inhibition by $\mathrm{PGI}_{2}$ of myometrial activity in vivo in non-pregnant ovariectomized sheep. $J$. Reprod. Fertil. 66:311-315.

44. Omini, C., G. C. Folco, R. Pasargiklian, M. Fano, and F. Berti. 
1979. Prostacyclin $\left(\mathrm{PGI}_{2}\right)$ in pregnant human uterus. Prostaglandins. 17:113-120.

45. Okita, J. R., N. Sagawa, M. L. Casey, and J. M. Snyder. 1983. A comparison of human amnion tissue and amnion cells in primary culture by morphological and biochemical criteria. In Vitro. 19:117126.

46. Korte, K., P. C. MacDonald, J. M. Johnston, J. R. Okita, and M. L. Casey. 1983. Metabolism of arachidonic acid and prostanoids in human endometrial stromal cells in monolayer culture. Biochim. Biophys. Acta. 752:423-433.

47. Casey, M. L., M. D. Mitchell, P. C. MacDonald, and J. M. Snyder. 1984. Maintenance and characterization of human myometrial smooth muscle cells in monolayer culture. In Vitro. 20:396-403.

48. Mitchell, M. D., and A. P. F. Flint. 1978. Prostaglandin production by intra-uterine tissues of periparturient sheep: use of a superfusion technique. J. Endocrinol. 76:111-121.

49. Mitchell, M. D. 1978. A sensitive radioimmunoassay for 6 keto-prostaglandin $F_{1 \alpha}$ : preliminary observations on circulating concentrations. Prostagl. Med. 1:13-21.

50. Lowry, O. H., N. J. Rosebrough, A. L. Farr, and R. J. Randall 1951. Protein measurement with Folin phenol reagent. J. Biol. Chem. 193:265-275.
51. Embrey, M. P. 1971. PGE compounds for induction of labour and abortion. Ann. NY Acad. Sci. 180:518-523.

52. Thiery, M. 1979. Induction of labor with prostaglandins. In Human Parturition. M. J. N. C. Keirse, A. B. M. Anderson, and J. Bennebroek-Gravenhorst, editors. Leiden University Press, Leiden. 155-164.

53. Zuckerman, H., and S. Harpaz-Kerpel. 1979. Prostaglandins and their inhibitors in premature labour. In Practical Applications of Prostaglandins and Their Synthesis Inhibitors. S. M. M. Karim, editor. MTP Press, Ltd., Lancaster, England. 411-435.

54. Casey, M. L., P. C. MacDonald, and M. D. Mitchell. 1984. Characterization of prostaglandin $E_{2}$ production by human amnion cells in monolayer culture. Prostaglandins. 27:421-428.

55. Keirse, M. J. N. C., and A. C. Turnbull. 1979. Metabolism of prostaglandins within the pregnant uterus. Br. J. Obstet. Gynaecol. 82: 887-893.

56. Lederman, R. P., D. S. McCann, B. Work, Jr., and M. J. Huber. 1977. Endogenous plasma epinephrine and norepinephrine in last trimester pregnancy and labor. Am. J. Obstet. Gynecol. 129:5-8.

57. Ogburn, Jr., P. L., S. B. Jonson, P. P. Williams, and R. T. Holman. 1980. Levels of free fatty acids and arachidonic acid in pregnancy and labor. J. Lab. Clin. Med. 95:943-949. 